\title{
Executive Compensation and Risk: An Empirical Study in Indonesia
}

\author{
A. Rahmat Setiawan \\ Airlangga University, Surabaya, Indonesia \\ B. Zunairoh \\ Airlangga University, Surabaya, Indonesia
}

\begin{abstract}
We investigate the relationship between executive compensation and risk for banks in Indonesia over the 2010-2013 period with 374 observations. Risk of banks measured by non-performing loan that implicated in loan risk. Non-performing loan as dependent variable. The executive compensation as independent variable. Firm size, firm age, and Capital Asset Ratio as control variable. Here, the result of the study indicates that executive compensation, firm age, and capital asset ratio have negative effect on risk and firm size has positive effect on risk.
\end{abstract}

\section{INTRODUCTION}

The banking institution is a financial institution that acts as an intermediary between excess funds and those who need funds. Banks collect funds from ecess funds in the form of savings current accounts, savings deposits, and deposits and rechannel funds obtained to the community in the form of credit. Banks must maintain health to maintain a sense of trust.

In the banking institution the achievement of maagement achievement can be shown through the way of management in anticipating business risks. According to Muwardi (2004) bank risk is the potential event of an event that can cause bank losses. The rapidly expanding internal and internal environment of banks will be followed by increasing complexity of risks for banking activities. One of the risks involved in banking is credit risk that occurs when the debtor does not fulfill its obligations to the bank such as principal repayment, interest payment, and others that will cause loss to the bank.

Bank owners reward executives in the form of compensation that has in recent years shown an increase. The compensation is given with the aim that executives can run the company well so as to minimize the risk. Increasing the salaries of national banking bankers is considered a natural thing. In the three years since 2007 , remuneration received by directors and bank commissioners has increased by $65 \%$ (2007-2010), averaging over $21 \%$ per annum. During 2010 the increase in remuneration of directors and bank commissioners was $19 \%$ or much higher compared to the previous year which was only $5 \%$ (Infobank, October 2011. H.6). Bankers in Indonesia receive the highest compensation compared to bankers in other countries in the ASEAN region. The compensation of bankers in Indonesia consisting of salaries, bonuses, regular allowances and other facilities in the form of natura and non-natura reaches $\mathrm{Rp}$
12 billion per year, while in Malaysia only Rp 5.6 billion per year, even in Filipina only Rp 1,1 billion per year or one twelfth of Indonesia (Infobank, October 2012. H.6). The remuneration of banks in Indonesia has been regulated by Indonesian banks with remuneration and nomination committees. However, remuneration given to banking executives is based on the Limited Liability Company Act (PT) in 2007. Salaries are set at the shareholders' meeting which becomes the highest forum of the shareholders.

Research on the effects of compensation on performance has been made in developed countries, especially the United States (US) and the UK (Murphy, 1999). This is due to the growing popularity of executive compensation issues and the ease of obtaining data through the stock exchange of large private companies in the country (Ramaswamy et al., 2000). According to Kato, Kim, and Lee, (2006), in developing countries, especially Asia, research on executive compensation is rarely done due to data constraints. The phenomenon also occurs in Indonesia. In Indonesia there is no regulation requiring companies to disclose the amount of compensation so that not all companies disclose the amount of compensation their executives receive. In addition, the company also greatly maintains the confidentiality of employee salaries, because it expresses the salary scale is still regarded as something sensitive.

Based on the background that has been mentioned above, then the problem formulation in this study is whether executive compensation with capital adequacy control variables, firm size, and age of the company affect the credit risk of banks in Indonesia?

\section{LITERATURE REVIEW}

\section{Understanding and Measurement of Credit Risk}

Credit risk, is one of the risks faced by the bank, namely the non-payment of loans that have been 
given to the debtor. According to Siamat (2004: 92) credit risk is a risk due to failure or inability of customers to return the loan amount received from the bank and its interest within the specified time period. The ratio used to gauge credit risk is non performing loan (NPL) with the formula:

NPL $=$ (Total problem loans) $/$ (Total credits $) \mathrm{x}$ $100 \%$.

This ratio shows the total amount of nonperforming loans to the total credit provided by the bank. Based on Bank Indonesia regulations, good NPLs are below 5\%. The higher the NPL ratio, the worse the performance of banks in managing credit, causing more and more problem loans to be borne by banks. The granting of credit aims to obtain profits derived from the difference between interest income on loans with interest expense deposits. Problem loans will cause a decrease in loan interest income due to the absence of principal and interest loan principal payments from the debtor.

\section{Understanding and Form of Executive Compen- sation}

Compensation according to Rivai (2010: 741) is the reward received by employees as a substitute for the contribution of services to the company. In this study, executive compensation is defined as a special compensation package designed for executivelevel employees. According to Sutrisno (2010: 184), the compensation based on the form of payment is divided into two, namely:

1. Financial compensation, is the compensation paid to employees in the form of money, in the form of basic salaries, bonuses, allowances, and incentive payments.

2. Non-financial compensation, is a compensation provided in kind or non-money, in the form of facilities or facilities to be owned or can not be owned.

In this study, executive compensation of banks can be paid in the form of financial and non-financial. The amount of compensation paid to bank executives is derived from the Good Corporate Governance report in the annual report of each bank.

\section{Measurement of Executive Compensation}

In this study the compensation in question is the compensation given to the board of directors. The total compensation of directors is obtained from remuneration in the form of salaries, bonuses, routine allowances, and tantiem plus other facilities in the form of housing, transportation, health, etc. either can be owned or not possessed (Infobank 2015: 61). The royalty compensation is a description of the size of the executive compensation that shows the amount of compensation received by executives each year. The magnitude of the predirection component is measured by the formula :

Compensation is pendireksi $=$ Ln ((Total Directors' Compensation) / (Number of Directors)) ......... (2.2)

\section{The effect of executive compensation on credit risk}

In the banking sector with high and competitive compensation to employees (especially executives) is expected to create productivity, profit, and business continues to grow. Banking sector in achieving good performance can not be separated from various risks such as credit risk.

Credit risk occurs if the debtor fails to fulfill its obligations to the bank such as principal payments, interest payments, etc. so that it will cause a loss to the bank. Credit risk must be well managed to maximize the rate of return to the bank. One way that the owner of the company to minimize credit risk is by giving bonus or compensation. Given the high compensation, the management owner hopes that the management can run the credit system well so that it can minimize credit risk. Based on the above description, this study is intended to examine the effect of compensation on credit risk.

H1: Executive compensation negatively affects credit risk.

\section{Company Size}

The size (size) of the company, is the amount of assets owned by the company. Large companies are better able to achieve economies of scale. Large-size banks are more competitive to obtain low-cost funds than small-size banks, as large banks are more trusted by the public. According to Sastradiputra (2004), the assets side of the bank shows management strategies and activities related to fund-raising areas including cash, accounts with central banks, shortterm and long-term loans, and fixed assets. The greater the ak-tiva or assets owned by a bank then the greater the volume of credit that can be channeled by the bank. Dendawijaya (2009) argues, the greater the volume of credit provides an opportunity for the bank to reduce the spread rate, which in turn will decrease the lending rate (loan interest rate) so that the bank will be more competitive in providing services to customers who need credit so that can accelerate credit payments and reduce the number of problem loans. The size of the company size is measured by the formula :

$S I Z E=L n$ (total aktiva)

H2: Size negatively affects credit risk.

\section{Age (Age) company}

The company's age, reflecting the length of the com- 
pany's standing in running its operations. The age of the company provides an opportunity to take advantage of the benefits associated with the company's reputation and experience. Banks with good reputations are likely to have future non-performing loan risk small, so the bank can run its operations smoothly. Banks that survive long periods of time with considerable experience can boost public confidence as banks are perceived to be able to deal with the risk of losses, so that the public will not be worried about saving funds in the bank. The size of the company's age is measured by the formula: $\mathrm{AGE}=$ year of research - year of establishment of company

H3: Age has a negative effect on credit risk.

\section{Capital adequacy}

Capital adequacy, is the availability of capital owned by banks to support assets that contain or generate risks. In accordance with Bank Indonesia Regulation Number 10/15 / PBI / 2008 that banks are required to provide a minimum capital of $8 \%$ of riskweighted assets. The bank's capital adequacy ratio is measured by the capital adequacy ratio (CAR), which shows how much the bank's assets contain the risks (credit, investment, securities, and claims to other banks) which can be anticipated by using its own capital. The size of a bank's CAR can be calculated by the formula:

CAR $=$ Capital $/($ Risk Weighted Assets $($ ATMR $)) \mathrm{x}$ $100 \%$

The higher the CAR value of a bank shows the better the bank's capital position, because it has sufficient capital to anticipate the potential losses caused by operational activities. High CAR values can lead to increased public confidence because they will not be worried when saving funds in the bank. Based on this understanding means that the bank's own capital is used to finance risk-bearing assets. The higher the capital the bank has, the easier it will be for banks to finance risk-bearing assets. Vice versa if high credit is not accompanied by sufficient capital it will potentially lead to problem loans. So it can be concluded that the higher the CAR, the lower the credit risk faced by the bank. Because if the credit disbursed then the credit risk will increase. According to Bank Indonesia (in Diyanti, 2012) states that capital has a negative effect on the problem condition.This gives a negative indication of the effect of CAR on NPL, it is in accordance with the results of research Diyanti (2012) in the study which states that CAR negatively against NPL.

H4: CAR negatively affects credit risk.

\section{METHODOLOGY}

\section{Model Analisis}

The analysis in this study using multiple linear analysis. By equation of regression model as follows:

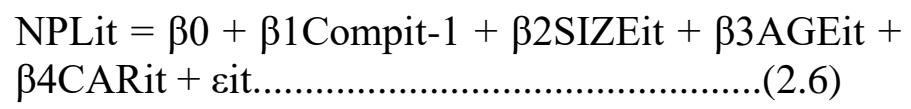

Information:

Compit-1 : Compensation of company executives i in year $\mathrm{t}-1$

CARIT : Capital Adequacy Ratio of company i in year $\mathrm{t}$

SIZEit : Company size $\mathrm{i}$ in year $\mathrm{t}$

NPLit : Credit risk of company $i$ in year $t$

AGEit : Age of company $i$ in year $t$

$\alpha \quad$ : Constants

$\beta(1,2,3,4)$ : Regression coefficient

cit : The fault factor or error of firm $i$ in year $\mathrm{t}$

I : Company sample

$\mathrm{t} \quad$ : Period of time (year)

\section{Types and data sources}

The data used in this study is secondary data contained in banking companies for the period 20102013. The data is sourced from the bank website concerned. For executive compensation sourced from research magazine Infobank October edition of 2011, 2012, 2013, and 2014.

\section{Operational definition}

To give a clear picture about the variables used in this study, the variables used in this study are defined as follows:

1. Credit risk is the risk of non-payment of loans that have been given to debtors, as measured by the ratio of non-performing loans (NPLs) using the formula (2.1).

2. Executive compensation is the average of the compensation of the debtor consisting of salaries, bonuses, and incentives paid in cash in one year. Executive compensation is obtained from Infobank from October 2012 to 2015 and is measured using the formula (2.2).

3. The size (size) of the company is the size of the company measured by the total natural logarithm of assets using the formula (2.3).

4. The age of the company is the length of time the company operates since the company was established until the 2010-2014 research year, as measured using the formula (2.4).

5. Capital adequacy is the availability of capital owned by banks to support risk-bearing assets, 
measured using capital adequacy ratio (CAR) by the formula (2.5).

\section{Sample Determination}

In this study the selected sample with purposive sampling method which means the sampling method based on certain criteria, namely:

1. A banking company that presents its annual financial statements that ends on 31 December.

2. Conventional commercial banks, not sharia or rural banks in 2010-2013.

3. Banking companies that publish the amount of compensation received by the director in total during 2009-2012.

\section{EMPIRICAL RESULTS}

\section{Description of Research Results}

In Table 1, the description of each variable analyzed in this research is presented.

\begin{tabular}{l} 
Table 1 \\
\multicolumn{7}{|c|}{ Descriptive Statistics } \\
\begin{tabular}{|l|c|c|c|c|c|}
\hline & N & Minimum & Maximum & Mean & Std. Deviation \\
\hline NPL (\%) & 372 & 0,03 & 8,89 & 1,74 & 1,48 \\
COM & 372 & 20,27 & 25,99 & 23,00 & 1,26 \\
\hline CAR (\%) & 372 & 8,07 & 75,04 & 18,46 & 8,61 \\
AGE & 372 & 20,00 & 87,00 & 46,38 & 13,89 \\
SIZE & 372 & 10,91 & 20,41 & 16,01 & 1,77 \\
Valid N (listwise) & 372 & & & & \\
\hline
\end{tabular}
\end{tabular}

The average NPL of the sample banks in 2010-2013 amounted to $1.74 \%$, the lowest value of $0.03 \%$ and the highest score of $8.89 \%$. This shows that there are still commercial banks in Indonesia that are above the provisions of Bank Indonesia. Based on Bank Indonesia regulations, good NPLs are below $5 \%$.

The compensation of bank executives who were sampled in 2009-2012 as measured by natural logarithm of compensation perempiration reached an average value of 23.00, the lowest value of 20.27 and the highest value of 25.99. This indicates that the compensation given to bank directors in Indonesia is varied.

The average CAR of banks that were sampled in $2010-2013$ was $18.46 \%$, the highest value of $8.07 \%$ and the highest value of $75.04 \%$. This indicates that commercial banks in Indonesia have complied with Bank Indonesia regulations to provide a minimum capital of $8 \%$ of risk-weighted assets.

\section{Hypothesis Analysis and Testing}

The results of the analysis of executive compensation effects, CAR, AGE, SIZE on NPLs and the results are summarized in Table 2.

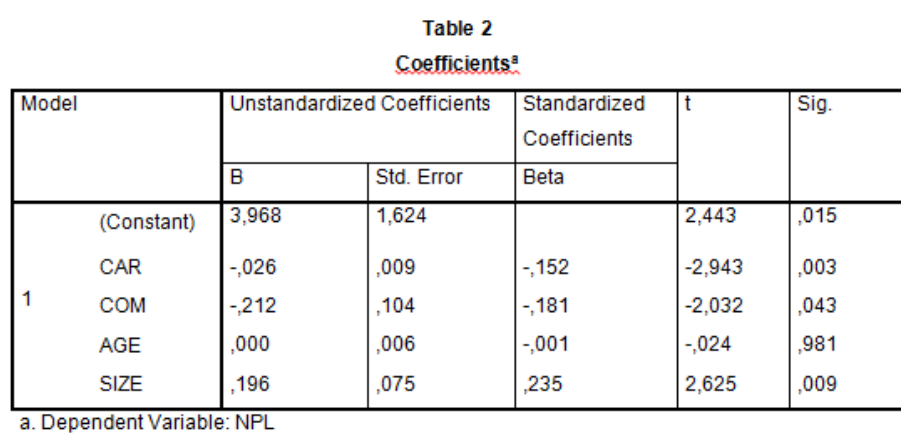

Table 2 shows that executive compensation variables, CAR, and AGE have a negative influence on NPLs, whereas SIZE has a positive effect on NPLs. The result of $t$ test shows that executive compensation variable, CAR, and AGE have no significant effect on NPL at $\alpha$ of 0.05 , while SIZE has significant effect on NPL at $\alpha$ equal to 0,05 .

\section{CONCLUSIONS}

Based on the results of data analysis that refers to the purpose of research, hypothesis, and model analysis, it can be drawn conclusion as follows:

1. executive compensation variables, CAR, and AGE have a negative influence on NPL, whereas SIZE has a positive influence on NPL.

2. The executive compensation variable, CAR, and AGE have no significant effect on NPL at $\alpha$ of 0.05 , while SIZE has significant effect on NPL at $\alpha$ of 0.05 .

\section{REFERENCES}

Adhi, Ramdhan. 2009. Analisis Risiko Perbankan. Jakarta: Salemba Empat.

Amstrong, Michael \& Helen Murlis. 2003. Reward Management. Alih Bahasa Ramelan Jilid 1. Edisi 1. Jakarta: PT Gramedia.

Angelo A. Unite a, Michael J. Sullivan. (2008). "Executive pay and firm performance in the Philippines". Pacific-Basin Finance Journal, Issue 16, pp. 606-623.

Anna, Zalewska. 2014. "Gentlemen do not talk about money: Remuneration dispersion and firm performance relationship on British boards". Journal of Empirical Finance, 27 40-57.

Arik \& Kato. 2010. "Correlation Corporate Productivity, Performance Assesment System and Salary System". Research Journal of International Studies, Issue 16, pp. 84-103.

Arun U., Ozgur. 2014. "Compensation practices in the lodging industry: Does topmanagement pay affect corporate performance? ". International Journal of Hospitality Management, 38 (2014) 30-38.

Bambang, s., Jati. 2010. “Analisis Pengaruh Dana Pihak Ketiga, BOPO, CAR dan LDR terhadap Kinerja Keuangan pada Sektor Perbankan yang Go 
Public di Bursa Efek Indonesia (BEI) (periode 20052008) ". Jurnal Dinamika Keuangan Dan Perbankan, hal: 125 - 137 vol. 2, no. 2. Issn 19794878.

Biro Riset Infobank. 2011. Remunerasi Bankir 2011. No. 39, Oktober 2011, Vol XXXIII. Majalah Infobank: Jakarta.

Brick, Palmon, Wald. 2005. "CEO compensation, director compensation, and firm performance". Journal of Corporate Finance, 12, 403 - 423.

Dini A., Islahuddin, Shabri. 2014. "Pengaruh Penerapan Manajemen Risiko terhadap Kinerja Keuangan Perbankan yang Terdaftar Di Bursa Efek Indonesia”. Jurnal Akuntansi Pascasarjana Universitas Syiah Kuala, Issn 2302-0164, 11 Pages Pp. 10- 20.

Elizabeth, K., Sousa. 2013. "Executive Compensation and Corporate Financial Performance: Empirical Evidences on Brazilian Industrial Companies". Journal of Modern Accounting and Auditing, ISSN 1548-6583

Ghozali, I. 2006. Analisis Multivariate dengan Program SPSS. Semarang: Badan Penerbit FakultasEkonomi Universitas Diponegoro.

Gudono. 2006. "The Role of Executive Compensation Schemes and Stock Ownership in Corporate Strategy, How They Affect Performance". Journal of Empirical Finance. issn, 0853-7046.

Judisseno, Rimsky K. 2002. Sistem Moneter dan Perbankan di Indonesia. Edisi pertama. Jakarta. PT. Grahamedia Pustaka Utama.

Kasmir. 2006. Manajemen Perbankan. Jakarta: PT Raja Grafindo Persada.

Kato,T., Kim,W., Lee,H.J. 2006. "Executive Compensation, Firm Performance, and Chaebol in Korea: Evidence from new panel data". Pasific-Basin $F i$ nance Journal, 15, 36-55.

Laarni. 2007. "Insentive CEO and firm performance". Research Journal of International Studies, Issue 16, pp. 606-623. May 2013, Vol. 9, No. 5, 650-661

Mahardian, Pandu. 2008. "Analisis Pengaruh rasio CAR, BOPO, NPL, NIM, dan LDR terhadap Kinerja Keuangan Perbankan (Studi Kasus Perusahaan Perbankan Yang Tercatat di BEJ Periode Juni 2002-Juni 2007) ". Tesis. Semarang Program Pascasarjana Universitas Diponegoro.

Ooi, Joseph. 1999. "Corporate Reliance On Bank Loan, An Empirical Analysis Of UK Property Companies". Journal of Property Investment \& Finance. Vol. 18 No. 1, pp. 103-120.

Peria, Mertinez dan Sergio L. Schmukler. 2001. "Do Depositors Punish Banks for Bad Behavior? Market
Dicipline, Deposito Inserance, and Banking Crises". The Journal of Finance. Vol LVI No. 3, 1029-1051. Ramaswamy. 2000. "A study of determinants of CEO compensationin India". Management International Review, 40, 167-191.

Rivai, Veithzal. 2010. Manajemen Sumber Daya Manusia untuk Perusahaan: Dari Teori ke Praktik. Jakarta: Rajawali Pers.

Siamat, Dahlan. 2004. Manejemen Perbankan. Edisi Kelima. Jakarta: Fakultas Ekonomi Indonesia.

Surat Edaran Bank Indonesia No. 6/23/DPNP Tanggal 31 Mei 2004 tentang Sistem Penilaian Tingkat Kesehatan Bank Umum.

Sutrisno, Edi. 2010. Manajemen Sumber Daya Manusia. Edisi Pertama. Jakarta: Prenada Media Group. 